\title{
Effect of zinc sulphate on the growth of mono- and multispecies cultures of some marine plankton algae
}

\author{
H. KAYSER \\ Biologische Anstalt Helgoland (Litoralstation); \\ List/Sylt, Federal Republic of Germany
}

\begin{abstract}
The effect of zinc sulphate has been investigated in mono- and multispecies cultures of the dinoflagellates Scrippsiella faeroense, Prorocentrum micans and Gymnodinium splendens and of the diatoms Scbroederella schroederi and Thalassiosira rotula. Multiplication rate, in vivo chlorophyll fluorescence, maximum cell densities and $\mathrm{Zn}$-conditioned disturbance of the species equilibrium of the multispecies cultures were used as criteria of sublethal toxic inhibition. In monocultures, the first effect became manifest after addition of 0.01 to $0.1 \mathrm{mg}$ $\mathrm{Zn}^{++} \cdot 1^{-1}$. Diatoms proved to be more sensitive than dinoflagellates. In multispecies cultures, the growth of each species depended on the ratio of the inocula. Interrelation between interspecific competition and $\mathrm{Zn}$-caused decrease in the number of algal cells regulated further growth of the cultures. Algal sensitivity to zinc increased with the number of species combined in the test medium: in a 5-species culture sublethal changes appeared already after addition of 0.005 to $0.01 \mathrm{mg} \mathrm{Zn}{ }^{++} \cdot 1^{-1}$. In a few cases, interspecific competition depressed the growth of some species to an appreciable extent, even in the control cultures. At the resulting low cell numbers, the effect of zinc became apparent only in higher concentrations from 5 to $10 \mathrm{mg} \mathrm{Zn}{ }^{++} \cdot 1^{-1}$. Morphological aberrations became manifest in Scrippsiella faeroense and in the diatoms in concentrations from 1 and $0.01 \mathrm{mg} \mathrm{Zn}^{++} \cdot 1^{-1}$ respectively. The results show that multispecies experiments are a more sensitive test method for investigating the influence of zinc on plankton algae than are monoculture experiments. In natural plankton communities, however, the toxicity of heavy metals may become effective at considerably lower limit concentrations; this is suggested by the simplified model investigations in the laboratory.
\end{abstract}

\section{INTRODUCTION}

In recent years increasing attention has been given to the determination of tolerance limits of marine plankton algae to heavy metal pollution. Laboratory experiments have been almost exclusively conducted with monocultures. This method freed the test algae from any interspecific competition to which they are exposed in the natural environment. To arrange experiments in a more realistic manner, in the present study multispecies cultures were used in a tolerance test for heavy metals in order to determine the sensitivity of the algae to toxicants under interspecific competition. By this means, it was expected that the disturbance of the species equilibrium of the test cultures could be determined to serve as a simple index of a polluted marine community in the natural environment. 
Interspecific interrelations of marine algae in culture were investigated among others by Pratt (1966), Whittaker \& Feeney (1971), Kroess (1971, 1972, 1973), Fedorov \& Kustenko (1972), Fletcher (1974) and Elbrächter (1976). Fisher et al. (1974) extended the method to a toxicity test and used phytoplankton communities for studying the effects of PCB. In the experiments demonstrated here, zinc sulphate was tested as an example of a toxic industrial waste product. The dinoflagellates Scrippsiella faeroense, Prorocentrum micans and Gymnodinium splendens and the diatoms Schroederella schroederi and Thalassiosira rotula served as test forms in monocultures and in combinations of 2, 3 and 5 species. Multiplication rates, maximum cell densities, in vivo chlorophyll fluorescence and morphological alterations of the cells served as criteria of toxic influences. Special attention was given to the interspecific variation of the multispecies cultures. Chipman et al. (1958), Cushing \& Watson (1968), Hayward (1969), Whitton (1970), Colman et al. (1971), Bartlett \& Rabe (1974) and Jensen \& Rystad (1974) investigated the tolerance limits and the effects of uptake-, accumulation- and $\mathrm{Zn}$-resistance of some other algal species. The results are discussed in comparison with those of the multispecies experiments.

\section{MATERIALS AND METHODS}

The dinoflagellates Scrippsiella faeroense (Paulsen) Balech et Soares, Prorocentrum micans Ehrenberg and Gymnodinium spendens Lebour and the diatoms Schroederella scbroederi (Bergon) Pavillard and Thalassiosira rotula Meunier were isolated near Helgoland and List, Sylt, and cultivated in unialgal mono- and multispecies cultures. In species combinations $S$. faeroense was joined with 1, 2 or 4 other forms. The culture medium consisted of natural seawater $(32 \pm 1.5 \% \mathrm{~S}$, sterile filtered through Millipore filter of $0.22 \mu \mathrm{m}$ pore diameter), enriched with $0.075 \mathrm{~g}$ $\mathrm{NaNO}_{3}, 0.005 \mathrm{~g} \mathrm{NaH}_{2} \mathrm{PO}_{4}$ and $0.015 \mathrm{~g} \mathrm{Na}_{2} \mathrm{SiO}_{3} \cdot 9 \mathrm{H}_{2} \mathrm{O}$ per liter seawater. Stock cultures were kept in $\mathrm{f} / 2$ medium, based on a recipe of Guillard \& Ryther (1962). The algae were cultivated in series of $5-1$ glass bottles (Jenaer glass, DURAN 50 ). Before use, the bottles were treated with $\mathrm{Zn}$ solutions (seawater + zinc sulphate) in concentrations corresponding to those used during the culture experiments in order to saturate the glass walls with zinc. $\mathrm{Zinc}$ was added as $\mathrm{ZnSO}_{4} \cdot 7 \mathrm{H}_{2} \mathrm{O}$ from a distilled water stock solution $\left(4.398 \mathrm{~g} \mathrm{ZnSO}_{4} \cdot 7 \mathrm{H}_{2} \mathrm{O}\right.$ in $\left.11 \mathrm{H}_{2} \mathrm{O}, 20^{\circ} \mathrm{C}\right)$ in amounts of 0.001 up to $100 \mathrm{mg} \mathrm{Zn}^{+}+$ions per liter culture medium once at the beginning of the experiments. All cultures were set up in constant-temperature rooms at $18 \pm 1{ }^{\circ} \mathrm{C}$. The bottles were illuminated by laterally-positioned daylight fluorescent lamps (Osram - L40 W/15) with a light intensity of about 3000 Lux. The distance from the light source to the bottles was $10 \mathrm{~cm}$. A $14: 10 \mathrm{~h}$ light : dark period was maintained. Cell counts and photomicrographs were made with an inverted microscope. The in vivo fluorescence of the algal cultures was determined by a Turner fluorometer. Samples were taken daily and at the same time $(10.00 \mathrm{~h})$. To achieve a homogeneous distribution of the algae a slight turbulence of the culture medium was obtained by aeration ( $40 \mathrm{ml} \mathrm{air} / \mathrm{min}$ ). 


\section{RESULTS}

\section{Monocultureexperiments}

The growth curves of the 5 test species indicate that dinoflagellates are considerably less sensitive to zinc than diatoms (Figs. 1-5). After addition of $1 \mathrm{mg} \mathrm{Zn}^{++} \cdot 1^{-1}$, for example, Scrippsiella faeroense showed only slightly inhibited multiplication rate and a reduced maximum cell density of $73 \%$ of that of the control culture (Fig. 1). Prorocentrum micans was decreased to $46 \%$ (Fig. 2) and Gymnodinium splendens to $3.5 \%$ (Fig. 3 ) of the maximum control cell numbers as can be seen from the 5 replicates that are run at this concentration. Scbroederella schroederi (Fig. 4) and Thalassiosira rotula (Fig. 5), however, were damaged completely after 2 days

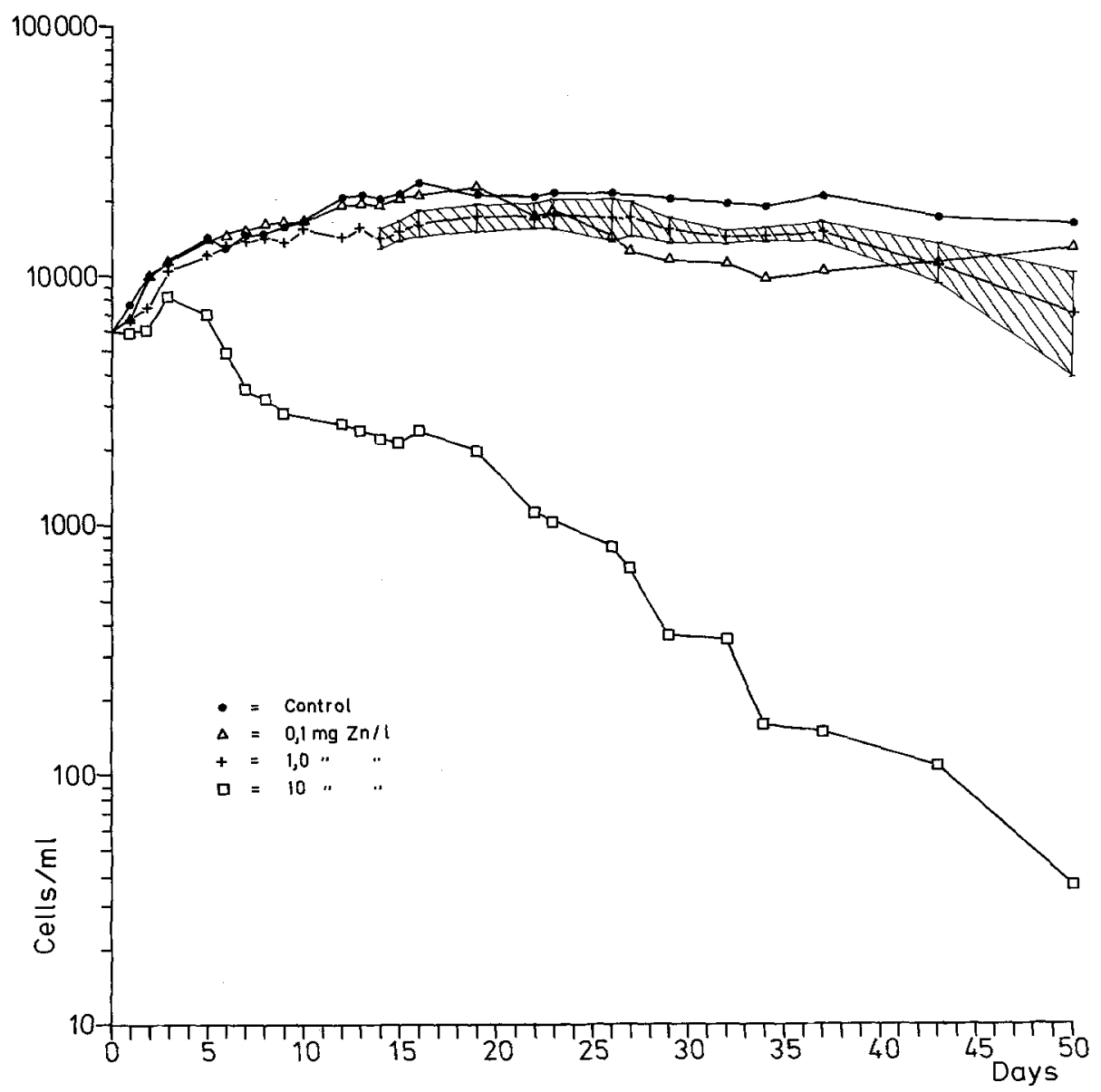

Fig. 1: Scrippsiella faeroense. Cell density following addition of zinc sulphate in amounts of 0.1 to $10 \mathrm{mg} \mathrm{Zn} \mathrm{Zn}^{++} \cdot 1^{-1}$. Mean values and standard deviations of 5 replicates are given for

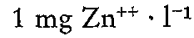


Effect of zinc on cultures of plankton algae

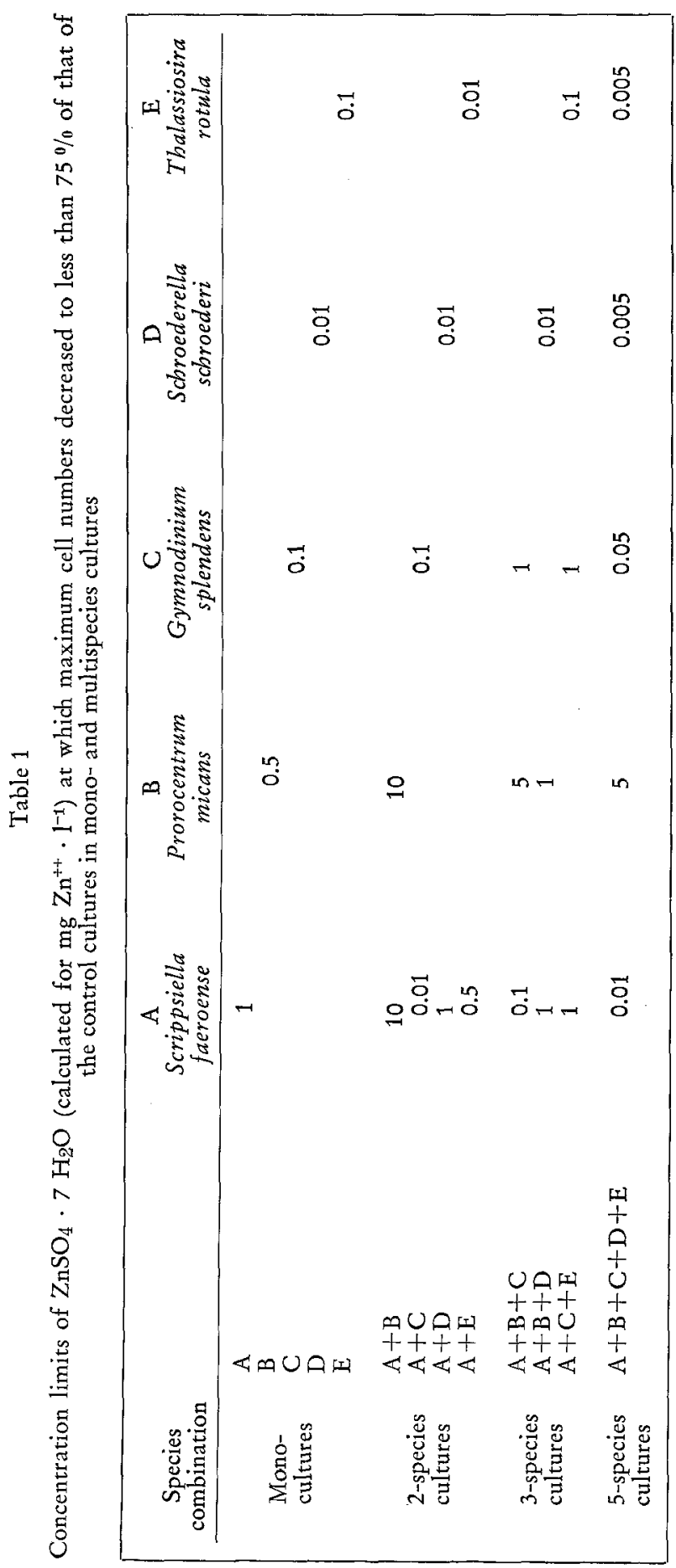


of exposure for the former, and one day for the latter species. The separate analysis shows that the dinoflagellates began to decrease after addition of $0.1 \mathrm{mg} \mathrm{Zn}^{++} \cdot 1^{-1}$. In $S$. faeroense the effect could not be seen before day 20. Break-down of the cultures took place after addition of 5 to $50 \mathrm{mg} \mathrm{Zn}^{++} \cdot \mathrm{l}^{-1}$. In diatoms the initial inhibition of growth already became manifest after addition of $0.01 \mathrm{mg} \mathrm{Zn}^{++} \cdot \mathrm{l}^{-1}$ in $S$. schroederi and $0.05 \mathrm{mg} \mathrm{Zn}^{++} \cdot 1^{-1}$ in $T$. rotula and the cultures were damaged at $0.5 \mathrm{mg} \mathrm{Zn}^{++} \cdot 1^{-1}$. The $\mathrm{Zn}$ addition which reduced the maximum cell numbers of the cultures to less than $75 \%$ of that of the controls are summarized in Table 1.

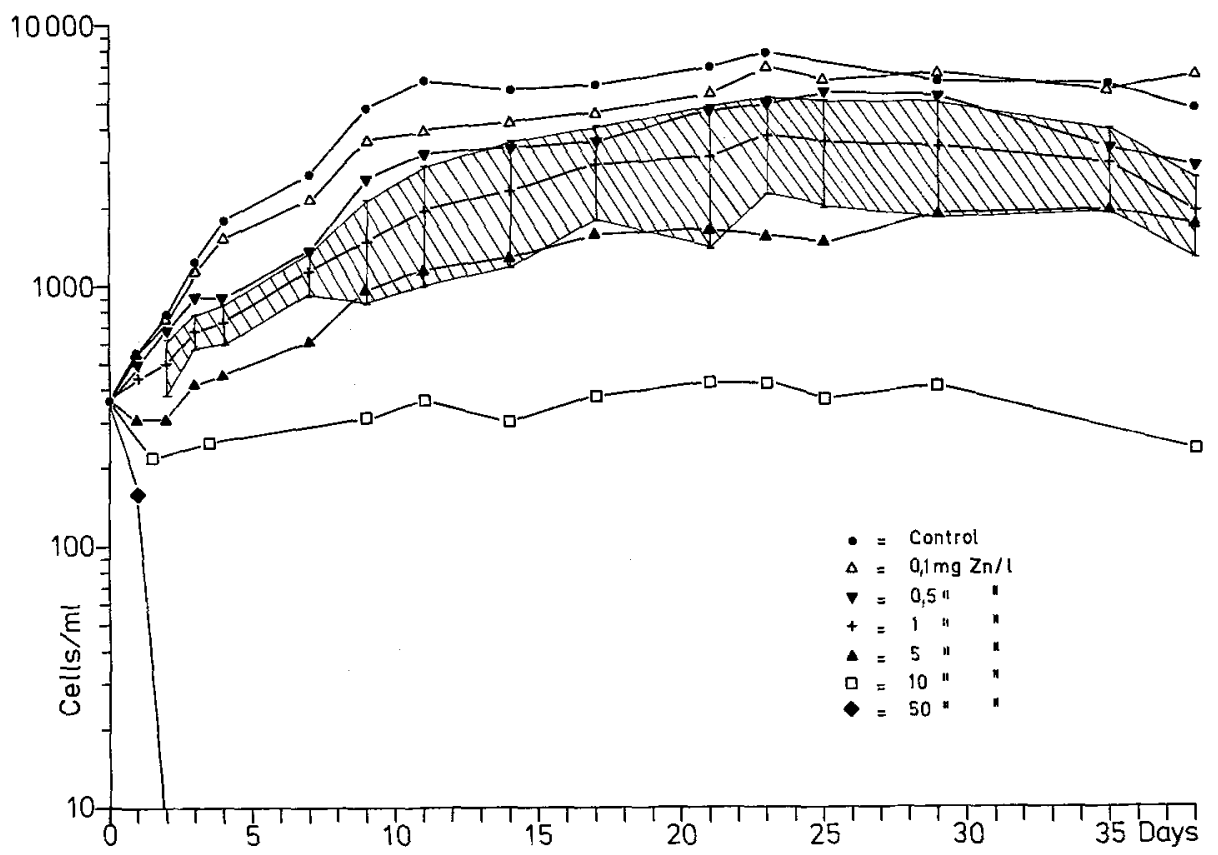

Fig. 2: Porocentrum micans. Cell density following addition of zinc sulphate in amounts of 0.1 to $50 \mathrm{mg} \mathrm{Zn}^{++} \cdot 1^{-1}$. Mean values and standard deviations of 5 replicates are given for $1 \mathrm{mg} \mathrm{Zn}^{++} \cdot 1^{-1}$

The in vivo chlorophyll fluorescence was investigated during the experiments with $S$. faeroense and G. splendens. In both cases the fluorescence of the cultures agreed very well with the cell counts. There was no evidence that in vivo chlorophyll fluorescence was more affected by $\mathrm{Zn}$ than was cell number. Analogous results were obtained in experiments on the toxicity of mercury (Kayser, 1976) and copper (Dr. S. M. Saifullah, personal communication).

Morphological aberrations occurred in $S$. faeroense. After adding 1 or $5 \mathrm{mg}$ $\mathrm{Zn}^{+}+1^{-1}$, respectively, the majority of the algae burst their thecae and hatched out in form of naked, oblong, motile cells. On the following day these cells had settled by forming hyaline pelliculae singly or in chains at the antapical end (Fig. $6 \mathrm{~A}, \mathrm{~B}$ and $\mathrm{C})$. In the succeeding days most of these cells died; only a few survived, 
possibly for more than 9 weeks, by forming solid membranes (Fig. 6 D). In 10, 50 and $100 \mathrm{mg} \mathrm{Zn}^{++} \cdot 1^{-1}$ the cells remained in the burst thecae, presumably handicapped by the acute toxic effect of the zinc. The same effects were observed with mercury (Kayser, 1976) and copper (Dr. S. M. Saifullah, personal communication) and a detailed description of the event is given in this publication.

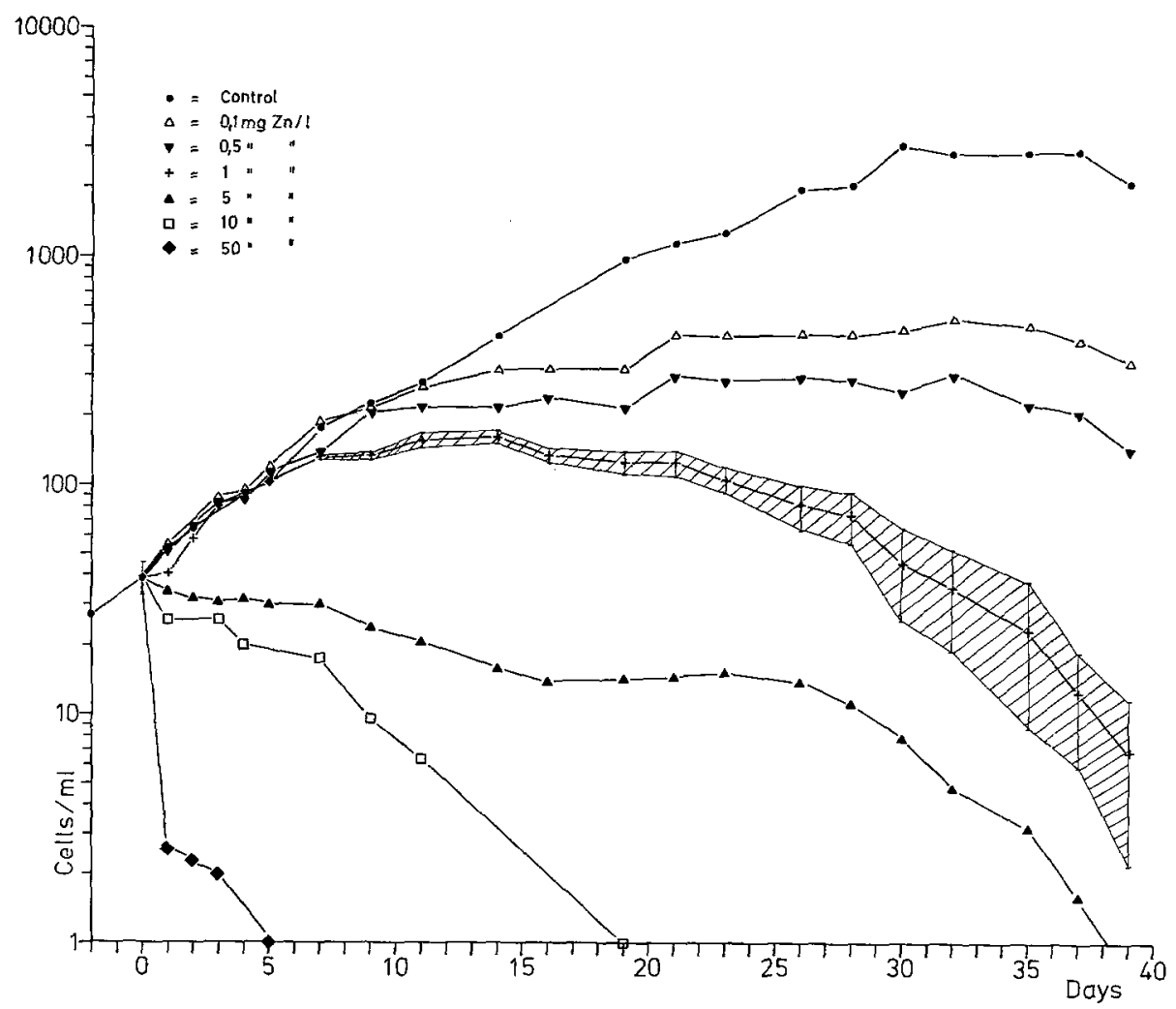

Fig. 3: Gymnodinium splendens. Cell density following addition of zinc sulphate in amounts of 0.1 to $50 \mathrm{mg} \mathrm{Zn^{++ }} \cdot \mathrm{I}^{-1}$. Mean values and standard deviations of 5 replicates are given for

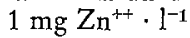

Recovery effects of $\mathrm{Zn}$-affected cells were investigated in an test series which was taken from the $5,10,50$ and $100 \mathrm{mg} \mathrm{Zn}^{++} \cdot 1^{-1}$ cultures on the 8 th day of the experiments. $20 \mathrm{ml}$ of the decreasing cultures were inoculated to every $1.5 \mathrm{l}$ of pure culture medium and only the cells of the $5 \mathrm{mg} \mathrm{Zn}^{++} \cdot 1^{-1}$ cultures proceeded to normal growth after a lag phase of one month ( $S$. faeroense).

$G$. splendens showed reduced locomotory activity immediately after addition of $5 \mathrm{mg} \mathrm{Zn}^{++} \cdot 1^{-1}$. At 10 and $50 \mathrm{mg} \mathrm{Zn}^{++} \cdot 1^{-1}$ all cells became motionless and deformed, taking a spherical shape. At $10 \mathrm{mg} \mathrm{Zn}^{++} \cdot 1^{-1}$ this deformation became noticeable, at $50 \mathrm{mg} \mathrm{Zn}++\cdot \mathrm{I}^{-1}$ it was complete; the affected cells died in a few days. 

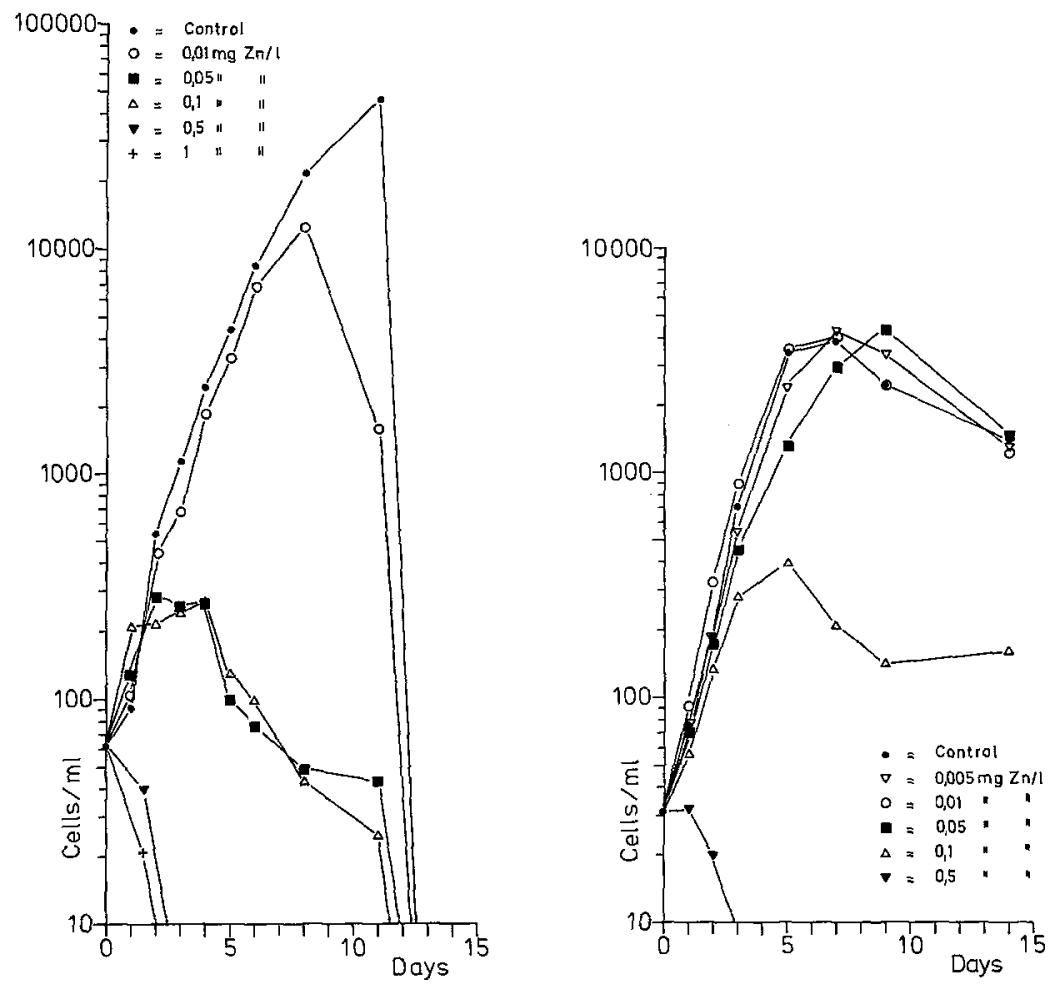

Fig. 4: Schroederella schroederi. Cell density following addition of zinc sulphate in amounts of 0.01 to $1 \mathrm{mg} \mathrm{Zn}^{++} \cdot 1^{-1}$

Fig. 5: Thalassiosira rotula. Cell density following addition of zinc sulphate in amounts of 0.005 to $0.5 \mathrm{mg} \mathrm{Zn}^{++} \cdot 1^{-1}$

S. schroederi and $T$. rotula were inhibited in cell division after addition of 0.1 and $0.01 \mathrm{mg} \mathrm{Zn}^{++} \cdot \mathrm{I}^{-1}$ respectively, resulting in abnormal long and curved cell sizes. The cell chains had been broken previously.

\section{2-species experiments}

Growth kinetics of 2-species cultures were investigated with respect to different initial cell densities. The results indicate that the ratio of the inocula was decisive for the growth capacity of the single species. Scrippsiella faeroense, for example, prevailed and depressed Prorocentrum micans as a result of a relatively greater inoculum; vice versa $P$. micans prevailed and depressed $S$. faeroense in spite of the greater multiplication rate of the latter species. At equal inocula growth of both species was depressed and led to nearly the same maximum cell numbers. The same trend was true in combinations of $S$. faeroense with Gymnodinium splendens and Schroederella schroederi. At greater inoculum the latter form dominated even before 

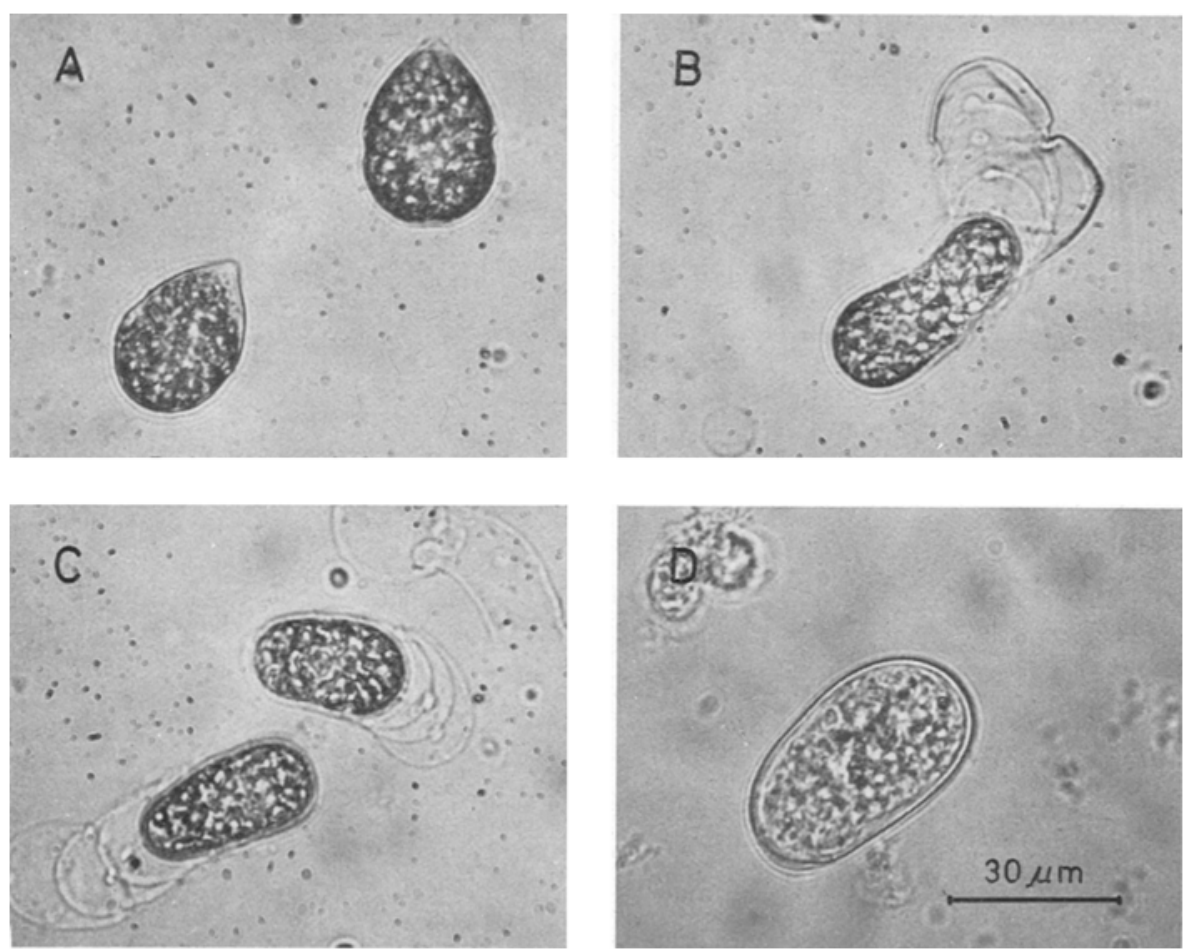

Fig. 6: Scrippsiella faeroense. Morphological variations following addition of zinc sulphate. (A) Cells from the control culture; (B) Emerged oblong cell attached to its burst empty theca one day after addition of $1 \mathrm{mg} \mathrm{Zn}^{++} \cdot 1^{-1}$; (C) Oblong cells, settled by forming hyaline pelliculae at the antapical end, one day after addition of $1 \mathrm{mg} \mathrm{Zn}^{++} \cdot 1^{-1}$; (D) Resting stage with a solid, smooth membrane 9 weeks after addition of $5 \mathrm{mg} \mathrm{Zn}^{++} \cdot 1^{-1}$. (All cells photographed from life)

S. faeroense could reach comparable cell densities whilst at lower inoculum S. schroederi was damaged even at the begin of the experiments. In the light of these results, the ratio of the initial cell densities of the contamination trials with zinc was chosen in such proportions that all species had a chance to grow up side by side.

\section{Scrippsiella faeroense + Prorocentrum micans}

At an inoculum of 330 cells $/ \mathrm{ml}$ of $S$. faeroense and 860 cells $/ \mathrm{ml}$ of P. micans the former species was depressed in the control culture abruptly after 14 days as expected from the preliminary experiments (Fig. 7 I A). The maximum cell densities of both species were reduced in comparison with the monoculture experiments. After addition of zinc in amounts up to $1 \mathrm{mg} \mathrm{Zn}^{++} \cdot 1^{-1}$ (Fig. $7 \mathrm{I} \mathrm{B}$ ) the cultures remained unaffected. Only at $10 \mathrm{mg} \mathrm{Zn}^{++} \cdot 1^{-1}$ the toxic effect of the metal reached such a degree that the cell numbers of both species were reduced to $22 \%$ ( $S$. faeroense) 

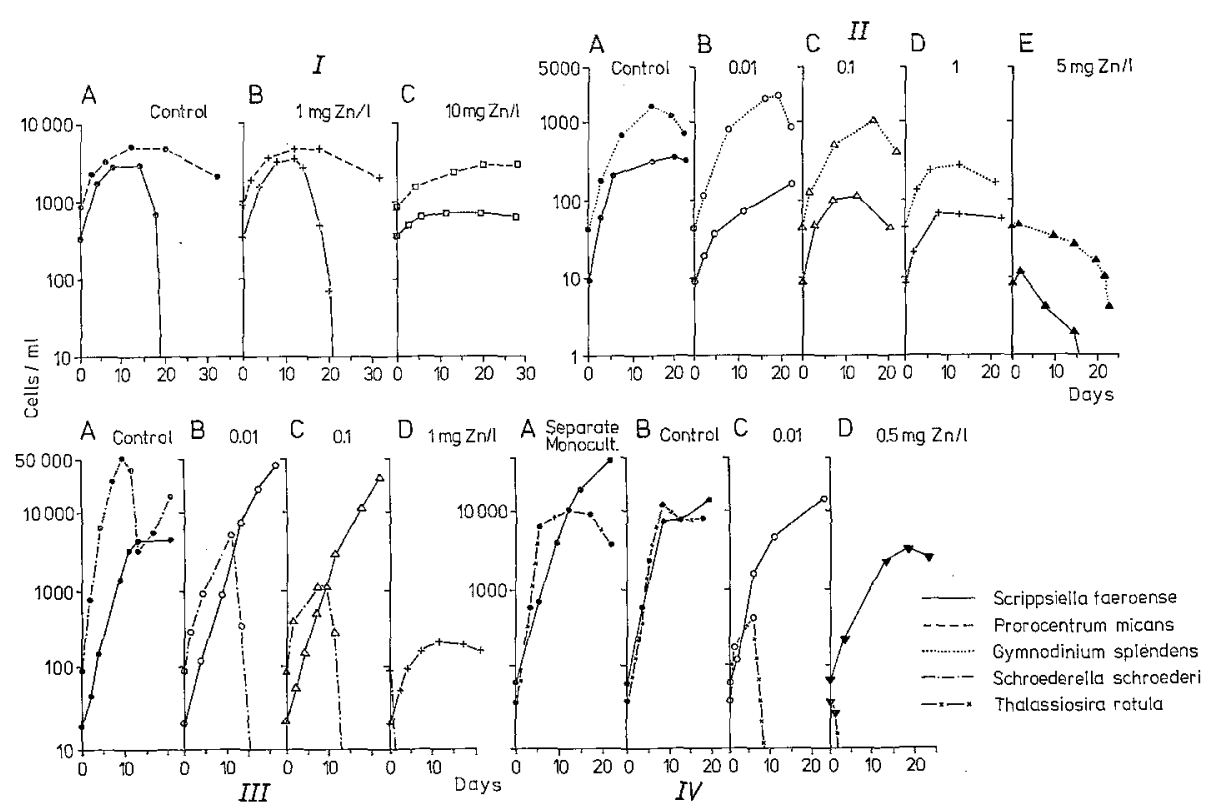

Fig. 7: 2-species cultures following addition of zinc sulphate in amounts of 0.01 to $10 \mathrm{mg}$ $\mathrm{Zn}^{++} \cdot 1^{-1}$. (I) Scrippsiella faeroense + Prorocentrum micans, (II) Scrippsiella faeroense + Gymnodinium splendens, (III) Scrippsiella faeroense + Scbroederella schroederi, (IV) Scrippsiella faeroense + Thalassiosira rotula

respectively $60 \%$ ( $P$. micans) of the maximum densities of the control combination (Fig. 7 I C). S. faeroense showed a prolonged stagnation phase at this $\mathrm{Zn}$ concentration, caused presumably by the sufficient nutient supply which was available at the low cell densities of both species (Table 1).

\section{Scrippsiella faeroense + Gymnodinium splendens}

Corresponding to the foregoing experiment, S. faeroense was inoculated with fewer cells than G. splendens and stagnated in the control culture after an exponential phase of only 6 days (Fig. 7 II A). Zn reduced the multiplication rate as well as the maximum cell density of this species already after addition of $0.01 \mathrm{mg} \mathrm{Zn}^{++} \cdot \mathrm{1}^{-1}$ (Fig. $7 \mathrm{II} \mathrm{B}$ ) and this was only the 100th part of the concentration required to cause a comparable toxic effect in the monoculture experiments. Interspecific competition and $\mathrm{Zn}$-involved toxic pressure enhanced each other in this case, apparently due to the fact that $G$. splendens influenced the other form not only by nutrient competition but also by inhibiting excretions, an assumption already made by Elbrächter (1976) who combined this species with Prorocentrum micans (see chapter "Discussion"). G. splendens was affected for the first time at a concentration of $0.1 \mathrm{mg}$ $\mathrm{Zn}^{++} \cdot 1^{-1}$ (Fig. 7 II C, D, E), corresponding to the results of the monoculture experiments (Table 1 ). 


\section{Scrippsiella faeroense + Schroederella schroederi}

At the given inocula the first toxic effect of $\mathrm{Zn}$ was visible in $S$. scbroederi after addition of $0.01 \mathrm{mg} \mathrm{Zn}^{++} \cdot 1^{-1}$ whilst $S$. faeroense remained unaffected (Fig. 7 III A, $B, C)$. The latter form reached at this concentration an even greater maximum cell density than the control, caused presumably by the better nutrient supply which was available due to the drastically reduced numbers of $S$. schroederi. S. faeroense was injured only at $1 \mathrm{mg} \mathrm{Zn}^{+}+\cdot \mathrm{1}^{-1}$ (Fig. 7 III D). The limiting $\mathrm{Zn}$ concentrations corresponded nearly to those of the monoculture experiments (Table 1 ).

\section{Scrippsiella faeroense + Thalassiosira rotula}

The growth of separate control cultures is given in Fig. 7 IV A. In the corresponding culture combination (Fig. 7 IV B) T.rotula reached nearly the same maximum cell density whilst $S$. faeroense stopped growth at this point presumably retarded by nutrient competition. Toxic decrease was visible after addition of $0.01 \mathrm{mg}$ $\mathrm{Zn}^{++} \cdot 1^{-1}$ (T. rotula, Fig. $7 \mathrm{IV} \mathrm{C}$ ) respectively at $0.5 \mathrm{mg} \mathrm{Zn}^{++} \cdot 1^{-1}$ (S. faeroense, Fig. 7 IV D). In comparison with the monoculture experiments both species showed an increased sensitivity to $\mathrm{Zn}$ (Table 1 ).

\section{$3-s p e c i e s$ experiments}

\section{Scrippsiella faeroense + Prorocentrum micans + Gymnodinium splendens}

In the control culture $S$. faeroense prevailed against the other two species (Fig. $8 \mathrm{I} \mathrm{A}$ ). Toxic decrease became manifest in this species after addition of $0.1 \mathrm{mg}$ $\mathrm{Zn}^{++} \cdot 1^{-1}$ (Fig. $8 \mathrm{I} \mathrm{B}$ ) and reduced the maximum cell number to nearly $10 \%$ of that of the corresponding control combination. In comparison with the monoculture experiments the sensitivity to $\mathrm{Zn}$ was raised ten fold (Table 1 ). The other two species remained at relatively low cell numbers, even in the control culture, and this may account for the fact that the effect of $\mathrm{Zn}$ was not visible before addition of $1 \mathrm{mg}$ $\mathrm{Zn}^{++} \cdot 1^{-1}$ in $\mathrm{G}$. splendens (40\% of maximum control cell number) respectively $5 \mathrm{mg} \mathrm{Zn}^{++} \cdot 1^{-1}$ in $P$. micans (Fig. $8 \mathrm{I} \mathrm{C}$ ).

\section{Scrippsiella faeroense + Prorocentrum micans + Schroederella scbroederi}

In the control culture $S$. schroederi showed a two-peaked growth curve whilst the two dinoflagellates counterbalanced each other at nearly equal lower cell densities (Fig. 8 II A). Addition of $\mathrm{Zn}$ decreased the maximum cell number of $S$. schroederi at $0.01 \mathrm{mg} \mathrm{Zn}^{++} \cdot 1^{-1}$ (Fig. 8 II B). In the dinoflagellates the toxic effect appeared at $1 \mathrm{mg} \mathrm{Z} \mathrm{Zn}^{++} \cdot 1^{-1}$ affecting $P$. micans more than $S$. faeroense (Fig. 8 II C). 

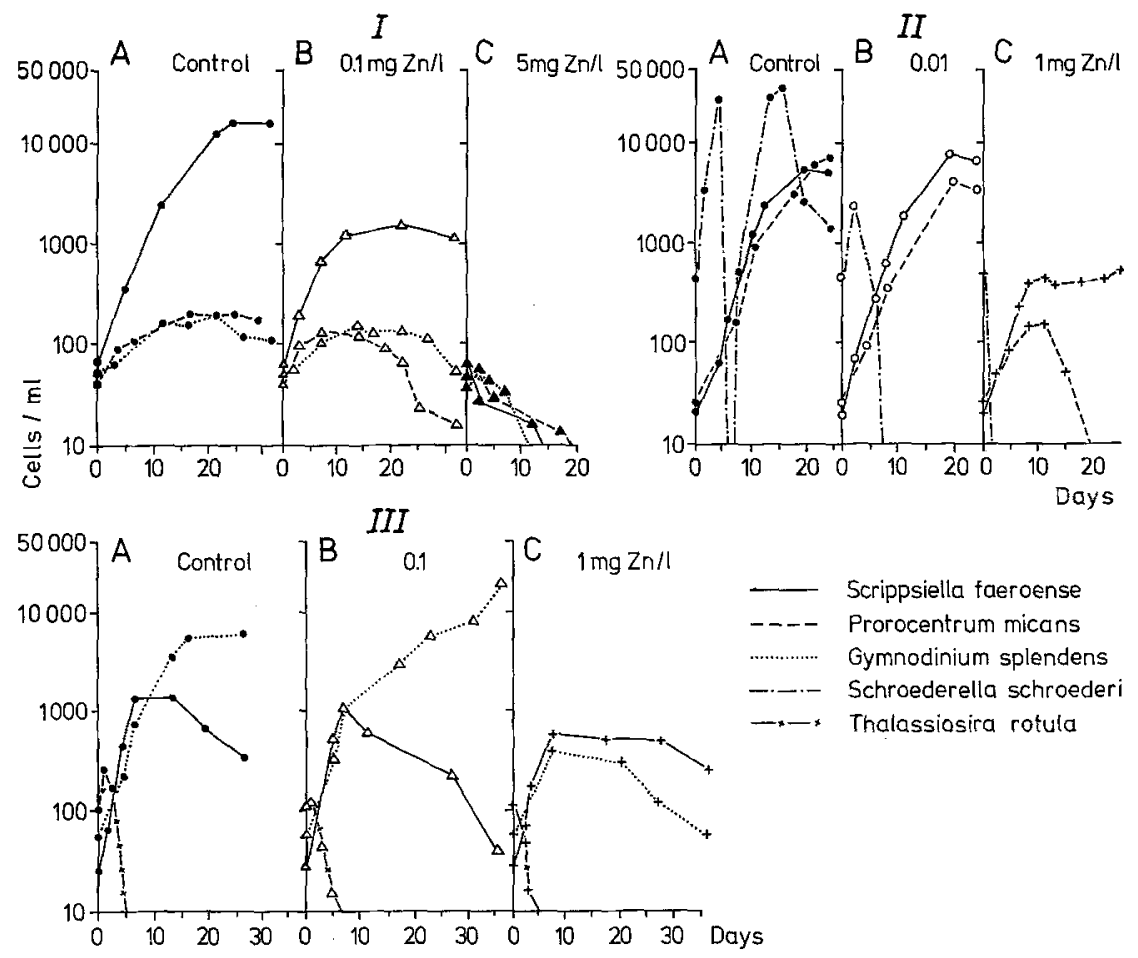

Fig. 8: 3-species cultures following addition of zinc sulphate in amounts of 0.01 to $5 \mathrm{mg}$ $\mathrm{Zn}^{++} \cdot 1^{-1}$. (I) Scrippsiella faeroense + Prorocentrum micans + Gymnodinium splendens, (II) Scrippsiella faeroense + Prorocentrum micans + Schroederella schroederi, (III) Scrippsiella faeroense + Gymnodinium splendens + Thalassiosira rotula

\section{Scrippsiella faeroense + Gymnodinium splendens + Thalassiosira rotula}

In the control combination G. splendens dominated whilst the other two species stopped growth after 7 and 1 days respectively (Fig. 8 III A). Toxic decrease became visible in $T$. rotula after addition of $0.1 \mathrm{mg} \mathrm{Zn}^{++} \cdot 1^{-1}$ (Fig. 8 III B). The dinoflagellates decreased not until addition of $1 \mathrm{mg} \mathrm{Zn}^{++} \cdot 1^{-1}$ (Fig. 8 III C).

\section{5-species experiments}

\section{Scrippsiella faeroense + Prorocentrum micans + Gymnodinium splendens + Scbroederella schroederi + Thalassiosira rotula}

The growth of separate monocultures is demonstrated in Fig. 9 A. The corresponding species combination (Fig. $9 \mathrm{~B}$ ) indicated a slightly reduced multiplication rate of $S$. faeroense whilst the other two dinoflagellates stopped growing after one week, followed by a stagnation phase at nearly equal cell densities. The two diatoms 

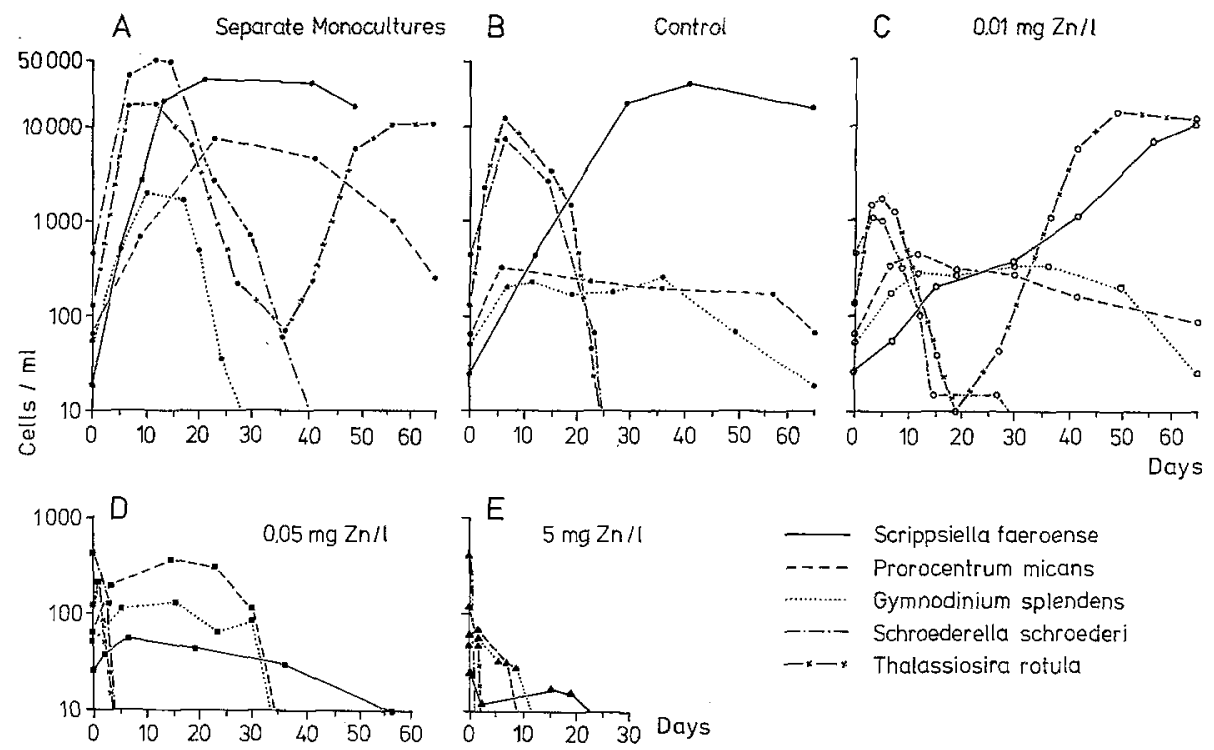

Fig. 9: 5-species cultures of Scrippsiella faeroense+Prorocentrum micans + Gymnodinium splendens + Schroederella schroederi + Thalassiosira rotula. Cell densities following addition of zinc sulphate: (A) Separate controls (Monocultures), (B) Control combination, (C) $0.01 \mathrm{mg}$

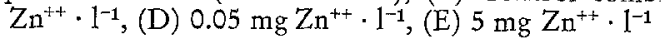

showed only slightly reduced maximum cell numbers and the effect was more evident in $S$. schroederi than in $T$. rotula. Addition of $\mathrm{Zn}$ in an amount of $0.005 \mathrm{mg} \mathrm{Zn}{ }^{++\cdot 1^{-1}}$ reduced the maximum cell number of $S$. schroederi to $24 \%$ and of $T$. rotula to $71 \%$ of the corresponding control combination. The other species remained unaffected (not figured). After addition of $0.01 \mathrm{mg} \mathrm{Zn}^{++} \cdot 1^{-1}$ the diatoms decreased to $13 \%$, respectively $14 \%$ of the maximum cell numbers of the control combination (Fig. $9 \mathrm{C}$ ) but $T$. rotula recovered to a second mass production which reached even greater cell numbers than the first one. In dinoflagellates only $S$. faeroense was inhibited at this concentration and showed reduction of its multiplication rate. Growth ceased visibly in all species after addition of $0.05 \mathrm{mg} \mathrm{Zn}^{++} \cdot 1^{-1}$ (Fig. $9 \mathrm{D}$ ) with exception of $P$. micans which was damaged only at $5 \mathrm{mg} \mathrm{Zn}^{++} \cdot \mathrm{I}^{-1}$ (Fig. $9 \mathrm{E}$ ). Comparison with the foregoing mono- and multispecies experiments indicates a generally increased sensitivity to $\mathrm{Zn}$. Only in Prorocentrum micans the effect was obscured by the interspecific competition which suppressed this species to relatively low cell densities even at the begin of the experiments (Table 1).

\section{DISCUSSION}

The growth of algal cultures in laboratory experiments depends strongly on the composition of the test media used. Variation of nutrient concentrations does not influence generation times but causes changes in the production rates of new cells 
(Elbrächter, 1976). In toxicity tests the sensitivity of the algae varies inversely with the concentration of the nutrients present (Hannan \& Patouillet, 1972). Investigations on the effects of heavy metals prohibit the addition of chelating agents to the test medium as they would immediately combine and form non-toxic complexes (Jensen \& Rystad, 1974). Therefore, in the investigations described, algal species were used which could be cultivated during experimental time in pure seawater enriched only with nitrate, phosphate and silicate. In multispecies cultures the growth of the single algal species is influenced by interspecific competition which implicates a contest for nutrients and inhibiting effects by toxic excretions of the algae themselves. Elbrächter (1976), for example, showed that Gymnodinium splendens inhibited the growth of Prorocentrum micans presumably by excretions, whereas $P$. micans had only an influence due to nutrient competition. Furthermore, the experiments verified that species equilibrium of multispecies cultures is balanced in accordance to the ratio of the algal species as defined at the start of the experiments. This interplay was examined in the present investigation only in preliminary experiments because the species equilibrium served mainly as basis of the inoculation densities of the corresponding contamination trials with addition of zinc.

Tolerance levels to $\mathrm{Zn}$ ions were investigated by Jensen \& Rystad (1974). In local water of the Oslo fjord Sceletonema costatum showed declining relative growth rates at $0.05 \mathrm{mg} \mathrm{Zn}^{++} \cdot 1^{-1}$. In $0.025 \mathrm{mg} \mathrm{Zn}^{++} \cdot 1^{-1}$ this species seemed to grow better in comparison with the control cultures but the maximum density of the cultures remained at comparably lower cell numbers. The growth of Thalassiosira psendonana declined at $0.25 \mathrm{mg} \mathrm{Zn}^{++} \cdot 1^{-1}$ and showed reduced maximum densities at 0.05 and $0.1 \mathrm{mg} \mathrm{Zn}^{++} \cdot 1^{-1}$ respectively. Phaeodactylum tricornutum began to decline at $25 \mathrm{mg}$ $\mathrm{Zn}^{++} \cdot 1^{-1}$. Intraspecific differences in the sensitivity to $\mathrm{Zn}$ were demonstrated in two clones of Sceletonema costatum. Chipman et al. (1958) established a reduced division rate of Nitzschia closterium after addition of $0.25 \mathrm{mg} \mathrm{Zn}^{++} \cdot \mathrm{H}^{-1}$ to a nutrient enriched seawater medium. Hayward (1969) used a synthetic medium containing $30 \mathrm{mg}$ EDTA $\cdot 1^{-1}$ which implies that all heavy metals are mainly in the chelated form. Pbaeodactylum tricornutum tolerated at least $1.15 \mathrm{mg} \mathrm{Zn}^{++} \cdot 1^{-1}$. Bartlett \& Rabe (1974) investigated the freshwater alga Selenastrum capricornutum, in which the

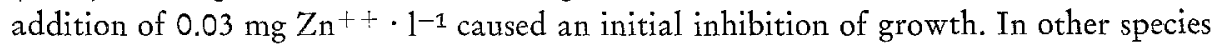
of fresh water algae (Colman et al., 1971) the growth, however, was enhanced at concentrations of $4.2 \mathrm{mg} \mathrm{Zn}^{++} \cdot 1^{-1}$. Even $8.1 \mathrm{mg} \mathrm{Zn}^{++} \cdot 1^{-1}$ retarded growth of Chlorella vulgaris and Euglena viridis and $18.03 \mathrm{mg} \mathrm{Zn}^{++} \cdot 1^{-1}$ that of Pediastrum tetras. In benthic freshwater algae "just non-inhibiting" values for $\mathrm{Zn}^{++}$ranged from 0.08 to $4.0 \mathrm{mg} \cdot 1^{-1}$ (Whitton, 1970).

The results, presented here, are restricted to the relative growth-inhibition of the algae following addition of definite amounts of zinc sulphate. Tolerance levels of zinc are demonstrated as $\mathrm{mg} \mathrm{Zn}^{++}$ions added initially to 11 of the culture medium. Chemical analyses on the location of the $\mathrm{Zn}$ during the experiments have not been carried out and should be subject of later investigations because it must be assumed that the concentration of the free $\mathrm{Zn}^{++}$ions in the medium decreased during the experiments by adherence to living and dead cells and to inorganic surfaces. Jensen \& Rystad (1974). for example, showed that the $\mathrm{Zn}$ content of Phaeodactylum 
tricornutum increased 200 times in cultures grown at $10 \mathrm{mg} \mathrm{Zn}^{++} \cdot 1^{-1}$ as compared to the control. Cushing \& Watson (1968) demonstrated an increased accumulation of $\mathrm{Zn}$ in dead cells compared with living cells and at least Tomlinson \& Renfro (1972) indicated a considerable $\mathrm{Zn}$ absorption by glass walls of culture bottles.

The experiments reveal the very complicated interdependences of interspecific competition and toxic $\mathrm{Zn}$ effects. Both factors regulate the growth of the multispecies cultures. Generally, the sensitivity to $\mathrm{Zn}$ increases with the number of species combined in one culture as can be seen from the results of the 5 -species experiments. A first effect becomes visible at maximum cell densitics. Fisher et al. (1974) confirmed these findings and showed that the toxicity of PCB was greatest when the algae were in competition with other species. This result can be obliterated by interspecific nutrient competition which depresses the maximum cell densities of single algal species to such an extent that the toxic decrease of the cultures does not become visible before adding relatively high amounts of $\mathrm{Zn}$. In such cases the limiting concentrations of $\mathrm{Zn}$ rose to considerably higher values than had been indicated from the monoculture experiments. On the other hand inhibiting excretions of the algae themselves may cause interactions in multispecies situations, which increase sensitivity to $\mathrm{Zn}$. Last but not least the Zn-effected decrease of sensitive species can favour the relative growth of less sensitive forms by cessation of the interspecific nutrient competition at maximum cell densities. It is not possible to separate these factors precisely during the experiments because they are superimposed on each other. Single effects could be demonstrated, therefore, on only a few characteristic examples which became apparent during the experiments. An application of the results to the situation of natural plankton communities suggests, however, that the toxicity of $\mathrm{Zn}$ may become effective at considerably lower limit concentrations than can be demonstrated by laboratory experiments. Interspecific interrelations with in situ conditions are considerably more complex than can be imitated in relatively simplified models. This should be considered especially in the assessment of industrial waste disposals into the sea; culture experiments can only be considered to be an approximation.

Acknowledgements. I gratefully acknowledge the Deutsche Forschungsgemeinschaft which supported this investigation by a grant. I express my thanks to Dr. G. Drebes for making available the cultures of Scrippsiella faeroense and Gymnodinium splendens and to Dr. M. Elbrächter for the determination of the former species. I am much obliged to Mrs. H. Harbst, Miss. U. Steinke and Miss. J. Willführ for technical assistance.

\section{LITERATURE CITED}

Bartlett, L. \& Rabe, F. W., 1974. Effects of copper, zinc and cadmium on Selenastrum capricornutum. Wat. Res. 8, 175-185.

Chipman, W. A., Rice, T. R. \& Price, T. J., 1958. Uptake and accumulation of radioactive zinc by marine plankton, fish and shellfish. Fish. Bull. U.S. 58, 279-292.

Colman, R. D., Colman, R. L. \& Rice, E. L., 1971. Zinc and cobalt concentration and toxicity in selected algal species. Bot. Gaz. 132, 102-109.

Cushing, C. E. \& Warson, D. G., 1968. Accumulation of ${ }^{22} \mathrm{P}$ and ${ }^{65} \mathrm{Zn}$ by living and killed plankton. Oikos 19, 143-145. 
Elbrächter, M., 1976. Population dynamic studies on phytoplankton cultures. Mar. Biol. 35, 201-209.

Fedorov, V. D. \& Kustenko, N. G., 1972. Competition between marine planktonic diatoms in monoculture and mixed culture. Oceanology 12, 91-100.

Fisher, N. S., Carpenter, E. J., Remsen, C. C. \& Wurster, C. F., 1974. Effects of PCB on interspecific competition in natural and gnotobiotic phytoplankton communities in continuous and batch cultures. Microb. Ecol. 1, 39-50.

Fletcher, R. L., 1975. Heteroantagonism observed in mixed algal cultures. Nature, Lond. 253, 534-535.

Guillard, R. R. L. \& Ryther, J. H., 1962. Studies of marine planktonic diatoms. I Cyclotella nana Hustedt and Detonula confervacea (Cleve) Gran. Can. J. Microbiol. 8, 229-239.

Hannan, P. J. \& Patouillet, C., 1972. Effect of mercury on algal growth rates. Biotechnol. Bioeng. 14, 93-101.

Hayward, J., 1969. Studies on the growth of Phaeodactylum tricornutum. V. The relationship to iron, manganese and zinc. J. mar. biol. Ass. U. K. 49, 439-446.

Jensen, A. \& Rystad, B., 1974. Heavy metal tolerance of marine phytoplankton. I. The tolerance of three algal species to zinc in coastal water. J. exp. Biol. Ecol. 15, 145-157.

Kayser, H., 1976. Waste water assay with continuous algal cultures: The effect of mercuric acetate on the growth of some marine dinoflagellates. Mar. Biol. 36, 61-72.

Kroess, H. W., 1971. Growth interactions between Chlamydomonas globosa Snow and Chlorococcum ellipsoideum Deadson and Bold under different experimental conditions, with special attention to the role of $\mathrm{pH}$. Limnol. Oceanogr. 16, 869-879.

- 1972. Growth interactions between Chlamydomonas globosa Snow and Chlorococcum ellipsoideum Deadson and Bold: the role of extracellular products. Limnol. Oceanogr. 17, 423-432.

- 1973. A spin filter system for the study of algae interactions. Oecologia 11, 93-98.

Pratt, D. M., 1966. Competition between Skeletonema costatum and Olisthodiscus luteus in Narragansett Bay and in culture. Limnol. Oceanogr. 11, 447-455.

Tomlinson, R. D. \& Renfro, W. C., 1972. Losses of ${ }^{65} \mathrm{Zn}$ to inorganic surfaces in a marine algal nutrient medium. Environ. Sci. Technol. 6, 1001-1005.

Whittaker, R. H. \& Feeney, P. P., 1971. Allelochemics: chemical interaction between species. Science, N. Y. 171, 757-770.

Whitton, B. A., 1970. Toxicity of zinc, copper and lead to chlorophyta from flowing waters. Arch. Microbiol. 72, 353-360.

Author's address: Dr. H. Kayser

Biologische Anstalt Helgoland (Litoralstation)

D - 2282 List / Sylt

Federal Republic of Germany 